\title{
REPRESENTASI KECANTIKAN PEREMPUAN JERMAN BERDASARKAN IKLAN NIVEA BERBAHASA JERMAN
}

\author{
Tryta Dessiliona \\ Program Studi Magister Linguistik Umum \\ Fakultas Ilmu Budaya Universitas Padjadjaran \\ trytaliona@gmail.com \\ Tajudin Nur \\ Fakultas Ilmu Budaya Universitas Padjadjaran \\ tajudin.nur@unpad.ac.id \\ Dian Indira \\ Fakultas Ilmu Budaya Universitas Padjadjaran \\ dian.indira@unpad.ac.id
}

\begin{abstract}
Abstrak
Penelitian ini bertujuan untuk mengungkapkan representasi kecantikan perempuan Jerman yang terdapat dalam iklan kecantikan Nivea berdasarkan makna denotasi dan konotasi dalam iklan. Penelitian ini merupakan suatu kajian semiotik dan menggunakan metode kualitatif yang bersifat deskriptif. Data diambil dari iklan kecantikan Nivea dalam majalah Brigitte. Majalah Brigitte merupakan majalah perempuan terbesar di Jerman. Teori yang digunakan dalam penelitian ini adalah semiotika dari Roland Barthes (1968) yang menjelaskan makna denotasi dan konotasi sebagai teori utama. Hasil penelitian menunjukkan bahwa iklan kecantikan Nivea merepresentasikan kecantikan perempuan Jerman mempunyai kulit wajah sehat, segar, kencang, dan terlihat muda. Perempuan Jerman juga tampil percaya diri dan cerdas walaupun dalam kesederhanaan.
\end{abstract}

Kata kunci: semiotika, iklan, kecantikan, bahasa Jerman

\begin{abstract}
This article aims to reveal the representation of German women's beauty based on the denotation and connotation of the Nivea advertisement. This research is a semiotic study and uses descriptive qualitative methods. Data was taken from Nivea beauty advertisements in German language. The Nivea ads were taken from Brigitte magazine. Brigitte magazine is the largest women's magazine in Germany. The theory used in the study is semiotics from Roland Barthes (1968) which explains the meaning of denotation and connotation as the main theory. The results showed that the Nivea beauty represents the beauty of German women having healthy, fresh, toned, and youthful facial skin. German women also appear confident and smart even in simplicity.
\end{abstract}

Keywords: semiotics, advertising, beauty, German language

\section{PENDAHULUAN}

Manusia berkomunikasi tidak hanya dengan bahasa lisan atau bahasa tertulis, namun bisa juga berkomunikasi dengan 'bahasa' tanda. Dalam kehidupan sehari-hari, masyarakat selalu dihadapkan dengan berbagai macam 
bentuk untuk menyampaikan informasi. Baik itu dalam bentuk cetak seperti dalam majalah, koran, papan reklame, atau video seperti yang beredar di televisi atau internet. Pada masa yang paling terkini, melalui aplikasi dalam telepon selular, manusia dapat menyampaikan informasi dengan mudah dan cepat. Kini hanya dengan menulis pesan melalui aplikasi chatting seperti whatsapp, line, atau media sosial lainnya pesan dapat tersampaikan. Di dalam penyampaian informasi tersebut ada berbagai macam tanda kebahasaan. Tanda dapat berbentuk verbal atau nonverbal dan dapat ditemui di mana saja. Tanda juga dapat berupa sebuah kata, gambar, simbol, atau emoticon. Agar tanda itu dapat dipahami oleh masyarakat, maka dibutuhkan konsep yang sama supaya tidak terjadi salah pengertian. Namun, pada kenyataannya tanda itu tidak selamanya bisa dipahami secara sama di masyarakat. Setiap orang memiliki interpretasi makna tersendiri dan tentu saja dengan berbagai alasan yang melatarbelakanginya. Perbedaan latar belakang usia, pendidikan, dan budaya dapat mempengaruhi interpretasi seseorang untuk memahami makna tanda yang dilihatnya.

Ilmu yang mempelajari sistem tanda adalah semiotika. Awal mulanya konsep semiotika diperkenalkan oleh Ferdinand de Saussure (1857-1913) melalui dikotomi sistem tanda: signifier dan signified atau signifiant dan signifié. Konsep ini melihat bahwa makna muncul ketika ada hubungan yang bersifat asosiasi atau in absentia antara 'penanda' (signifier) dan 'petanda' (signified). Saussure dalam (Danesi, 2012:30) menggambarkan tanda sebagai struktur biner, yaitu struktur yang terdiri dari dua bagian: (1) bagian fisik, yang disebut sebagai penanda (signifier), dan (2) bagian konseptual, yang disebut sebagai petanda (signified). Dari segi relasi $\mathrm{X}=\mathrm{Y}, \mathrm{X}$ merupakan penanda dan $\mathrm{Y}$ merupakan petanda. Saussure menganggap tautan antara penanda dan petanda, $X=Y$, bersifat manasuka (arbitrer). Contoh pada tree (pohon) untuk menunjukkan sebuah tumbuhan tinggi berdaun dan bercabang sebagai penanda (X), sedangkan bentuk dari pohon itu sendiri yang telah dipersepsikan oleh seseorang dalam pikirannya adalah petanda (Y). Pemikiran semiotika Saussure ini kemudian dikembangkan oleh Roland Barthes (1968). Barthes mengembangkan semiotika yang berakar dari penanda (signifier) dan petanda (signified) yang dapat menghasilkan makna baru yaitu makna denotasi dan konotasi.

Berbeda dengan Peirce dalam (Nöth, 2000: 62) yang membagi tiga pengklasifikasian tanda yaitu berdasarkan reprasentamen, objek, dan interpretan. Tanda atau reprasentamen adalah penggunaan tanda yang merupakan perwakilan sesuatu yang lain yaitu objek yang berada dalam kaitan suatu gagasan tertentu atau konteks dan menghasilkan suatu penafsiran di dalam masing-masing pikiran, baik itu pemikiran yang sama atau pemikiran yang lebih berkembang yang disebut dengan intrepretan.

Peirce dalam (Danesi, 2012: 34) mengidentifikasi tanda berdasarkan objeknya melalui tiga tanda yang lazim digunakan, yaitu: ikon, indeks, dan simbol. Ikon adalah tanda yang menyerupai benda yang diwakilinya atau suatu tanda yang menggunakan kesamaan atau ciri-ciri yang sama dengan apa yang 
dimaksudkannya. Misalnya, kesamaan sebuah peta dengan wilayah geografis yang digambarkannya, foto, dan lain-lain. Indeks adalah tanda dirancang untuk mengindikasikan sumber acuan atau sesuatu yang dituju atau saling menghubungkan sumber acuan dengan yang lain. Indeks, dengan demikian adalah suatu tanda yang mempunyai kaitan atau kedekatan dengan apa yang diwakilinya. Misalnya jari yang menunjuk, kata keterangan seperti di sini, di sana, kata ganti aku, kau, ia, dan sebagainya. Simbol adalah untuk menyandikan sumber acuan melalui kesepakatan atau persetujuan. Sebagai contoh simbol sosial seperti mawar, simbol matematika, dan seterusnya.

Semiotika erat kaitannya dengan tanda sebagai fokus utamanya sebagaimana telah dijelaskan sebelumnya, sementara itu iklan merupakan media yang banyak menggunakan tanda. Media massa mempunyai berbagai macam bentuk, salah satu bentuk dari media massa adalah iklan. Iklan merupakan salah satu media komunikasi untuk menyampaikan pesan dari produsen kepada konsumen. Apa yang harus dilakukan dalam kegiatan beriklan harus lebih dari sekedar memberikan informasi akan produk- produk yang ditawarkan kepada konsumen, melainkan juga mengubah sikap konsumen (Dewi, 2013:63). Untuk membuat iklan yang baik harus dibangun dengan rumus dan elemen-elemen iklan. Menurut Schlüter (2007: 25) iklan yang baik adalah iklan yang mengandung rumus AIDA, yang merupakan singkatan dari Attention 'perhatian', Interest 'minat', Desire 'keinginan', Action 'aksi'. Dalam Attention, iklan harus mampu menarik perhatian khalayak ramai sebagai sasaran dan untuk Interest, bagaimana agar konsumen berminat dan memiliki keinginan lebih jauh. Dalam hal ini dimaksudkan agar konsumen merasa terangsang untuk membaca dan mendengar pesan yang disampaikan dari iklan. Selain itu, iklan juga harus mampu menggerakkan keinginan pembaca untuk membeli atau memiliki produk yang ditawarkan, hal ini termasuk dalam rumus Desire. Kemudian iklan juga sebaiknya mengandung rumus Action yang berarti berusaha membujuk calon pembeli agar sesegera mungkin untuk membeli produk yang ditawarkan. Selain itu, dalam iklan terdapat pula elemen-elemen yang dapat memperkuat sebuah produksi iklan yaitu, headline, bodycopy, slogan, nama produk, elemen gambar, dan elemen warna (Janich, 2010: 53-76).

Warna dalam iklan juga berperan penting dalam pencitraan sebuah produk. Warna memiliki arti yang berbeda-beda dalam tradisi atau budaya tertentu. Arti warna dapat diartikan menurut cara pandang masyarakat di suatu wilayah tertentu. Warna digunakan dalam iklan juga bermaksud untuk menegaskan makna dari tanda dalam iklan tersebut. Sebagai contoh warnawarna lembut pada iklan produk pelembab kulit wanita yang memberikan kesan lembut dan nyaman. Menurut Heller dalam (Zulkarnaen \& Ajie, 2014) beberapa jenis warna memiliki makna tertentu bagi masyarakat Jerman, pemaknaan ini didasarkan pada survei yang telah dilakukan oleh Heller, yaitu:

1. Warna merah, bagi masyarakat Jerman warna merah disimbolkan sebagai warna keberanian, kasih sayang, dan kekuasaan.

2. Warna putih, masyarakat Jerman menggambarkan warna putih sebagai warna netral yang melambangkan kemurnian, kebersihan, kedewasaan, dan kesempurnaan. 
3. Warna hijau, masyarakat Jerman mengasosiasikan warna hijau sebagai warna alam yang dapat memberikan ketenangan, keharmonisan, dan pelepas stress.

4. Warna biru, warna ini melambangkan ketenangan, kebebasan, kesejukan, kesetiaan, keharmnonisan, kedamaian dan kestabilan. Dalam iklan suatu produk, warna biru sering dikombinasikan dengan berbagai warna, seperti hijau, putih, dan emas. Untuk warna biru terang memberikan makna kesegaran dan kesejukan. Penggunaan warna biru dan putih pada kemasan produk tertentu dapat memberikan asosiasi kepercayaan.

5. Warna kuning, warna ini menyimbolkan matahari yang dapat memberikan makna kehangatan, kegembiraan, keramahan, dan kesegaran.

6. Warna hitam, warna ini dapat memberikan efek positif, seperti warna hitam yang terdapat pada produk kosmetik dianggap dapat menyimbolkan kesan bahwa produk tersebut bernilai tinggi.

7. Warna hitam juga melambangkan sifat kuat, elegan, serius, pintar, dan berorientasi tinggi.

8. Warna coklat, warna ini dapat memberikan efek kenyamanan dan kehangatan.

9. Warna abu-abu, warna ini menyimbolkan kesan kesederhanaan, kemelaratan, dan kesedihan. Warna ini juga memberikan kesan elegan, netral, dan dewasa.

Dari sudut pandang ilmu linguistik, unsur-unsur iklan dikategorikan ke dalam tanda-tanda bahasa karena unsur-unsur tersebut memiliki makna. Dari elemen-elemen dalam iklan dapat menimbulkan kesan tertentu bagi masyarakat yang melihat dan membacanya. Tanda nonverbal dari iklan dianggap dapat mengaktifkan citra visual dan memberikan keyakinan verbal sehingga dapat mempengaruhi perasaan dan kepercayaan.

Secara sederhana iklan dapat dipahami sebagai media untuk memasarkan suatu produk. Pesan yang disampaikan dalam teks akan dipahami oleh pembaca sehingga makna dapat dihasilkan. Makna tersebut dapat berkembang menjadi suatu konsep yang dapat dimengerti oleh pembaca. Dalam banyak hal makna atau arti suatu pesan disampaikan secara implisit atau bersifat konotatif, maka makna tadi tidak bisa ditafsirkan sebagai apa yang tampak nyata dalam teks atau secara denotatif.

Barthes (2012) dalam bukunya Elements of Semiology menjelaskan secara rinci tingkatan pertandaan yang disebut dengan semiotika konotatif. Barthes yang dikutip dalam (Situmeang, 2015) menyebutnya sebagai denotasi, yaitu makna paling nyata dari tanda. Dalam konsep Barthes, tanda konotatif tidak sekedar memiliki makna tambahan namun juga mengandung kedua bagian tanda denotatif yang melandasi keberadaannya. Dalam hal ini, denotasi diasosiasikan dengan ketertutupan makna. Konotasi adalah istilah yang digunakan Barthes untuk menunjukkan signifikasi tahap kedua. Hal ini menggambarkan interaksi yang terjadi ketika tanda bertemu dengan perasaan 
atau emosi dari pembaca serta nilai-nilai dari kebudayaannya. Konotasi mempunyai makna yang subjektif atau paling tidak inter subjektif. Dengan kata lain, denotasi adalah apa yang digambarkan tanda terhadap sebuah objek, sedangkan konotasi adalah bagaimana menggambarkannya.

Representasi menurut (Danesi, 2010: 3) merupakan aktivitas membentuk ilmu pengetahuan yang dimungkinkan kapasitas otak untuk dilakukan oleh semua manusia. Lebih jelasnya representasi adalah sebagai penggunaan tanda (gambar, bunyi, dan lain-lain) untuk menghubungkan, menggambarkan, memotret, atau mereproduksi sesuatu yang dilihat, diindera, dibayangkan, atau dirasakan dalam bentuk fisik tertentu. Hall dalam (Winarni, 2010) mengemukakan bahwa pemahaman utama dari teori representasi adalah menggunakan bahasa untuk menyatakan sesuatu secara bermakna, atau mempresentasikan pada orang lain. Representasi merupakan bagian penting dalam proses di mana bahasa diproduksi dan dipertukarkan di antara simbolsimbol yang ada. Representasi melibatkan penggunaan bahasa dalam tandatanda (sign-sign) dan image-image yang mewakili atau mempresentasikan sesuatu.

Cantik adalah kata yang paling diharapkan oleh semua perempuan manapun, baik dalam maupun luar negeri. Semua perempuan akan sangat berharap dirinya menjadi cantik dan dikagumi banyak orang. Cantik dalam Kamus Besar Bahasa Indonesia (2008: 243) adalah elok, molek (tentang wajah, muka perempuan). Dalam Kamus Bahasa Indonesia-Jerman (Heuken, 2009: 88) cantik adalah hübsch [hypf]. Kata hübsch dalam kamus Duden Das Bedeutungswörterbuch (Razum, 2010: 506) "Aussehen angenehm, von einer Beschaffenheit, Erscheinung, die Wohlgefallen erregt. " yang berarti 'penampilan menyenangkan, dari alam, penampilan yang membangkitkan kesenangan'. Menurut Wolf dalam (Sebayang, 2017) kecantikan para perempuan, baik yang berkulit putih, berkulit hitam, maupun sawo matang, perempuan yang tampak sebagai para model fashion menyatakan mereka tahu sejak awal mereka dapat berpikir secara sadar bahwa sosok yang ideal adalah sosok yang kurus, tinggi, putih, dan berambut pirang dengan wajah yang mulus tanpa noda, simetri, dan tanpa cacat sedikitpun. Standar kecantikan wanita Eropa merupakan standar kecantikan yang dianggap ideal oleh hampir seluruh wanita. Memiliki kulit terang, rambut pirang, bermata biru, hidung mancung kecil, bertubuh kecil (termasuk payudara dan bokong), dan terlihat innocent seperti anak kecil (Sebayang, 2017).

Di Jerman sendiri begitu banyak iklan kecantikan yang dipasarkan. Iklaniklan itu dikemas dengan sederhana dan menampilkan figur perempuan yang memiliki karakteristik kulit yang berbeda-beda. Salah satunya Nivea sebagai merek dagang perawatan kulit terkenal yang berasal dari Jerman dan telah mendunia dan selalu menampilkan figur perempuan, serta kalimat yang menarik dalam iklannya. Hal ini berbeda dengan tampilan iklan di Indonesia yang tidak saja cantik tetapi juga dengan riasan yang lebih seronok.

Berdasarkan penjabaran di atas, penulis memilih untuk mengkaji representasi kecantikan perempuan Jerman dalam iklan Nivea berbahasa Jerman berdasarkan tanda verbal dan nonverbal dan makna yang terdapat dalam iklan. Penulis mengambil iklan kecantikan Nivea sebagai bahan penelitian dari majalah 
Brigitte dalam bentuk cetak yang terbit pada tahun 2018. Majalah Brigitte merupakan majalah perempuan terbesar di Jerman.

\section{METODE PENELITIAN}

Dalam penelitian ini digunakan metode kualitatif. Menurut (Djajasudarma, 2010: 11) mengungkapkan bahwa metode kualitatif merupakan prosedur yang menghasilkan data secara deskriptif baik itu tulis maupun lisan yang berkembang atau berada di masyarakat bahasa. Metode deskriptif bertujuan mengumpulkan informasi secara rinci dan mengidentifikasikan masalah. Data yang digunakan dalam penelitian ini bukan merupakan angka, melainkan berupa tanda verbal dan nonverbal yang ada pada data. Tanda verbal berupa kata-kata deskriptif yang ada pada data. Sementara tanda nonverbal berupa tanda lain selain tanda verbal yang ada pada data. Penelitian ini terdiri atas tiga tahap penelitian yaitu tahap penyediaan data, tahap analisis data, dan tahap penyajian hasil analisis data. Berikut adalah metode dan teknik yang digunakan dalam masing-masing tahap. Penulis menggunakan metode penelitian menurut (Sudaryanto, 2015)

Pengumpulan data dilakukan dengan metode simak serta metode lanjutan berupa teknik catat. Metode simak adalah proses menyimak penggunaan bahasa yang dijabarkan dalam berbagai wujud teknik sesuai dengan alatnya (Sudaryanto, 2015: 203). Metode simak dilakukan dengan mengumpulkan iklan kecantikan Nivea yang bersumber dari majalah Brigitte yang diterbitkan sepanjang tahun 2018. Dalam penelitian ini, penulis mengambil data berupa 3 iklan kecantikan Nivea. Ketiga iklan kecantikan tersebut bertema tentang produk perawatan wajah. Majalah Brigitte merupakan majalah perempuan berbahasa Jerman. Penulis memperoleh majalah ini di Goethe Institut Bandung. Penulis memperoleh data dengan cara mencatat bentuk yang relevan bagi penelitian.

Metode yang digunakan untuk menganalisis data dalam penelitian ini adalah metode padan dengan alat penentunya berdasarkan daya pilah referensial dan daya pilah translasional (Sudaryanto, 2015: 32). Metode padan adalah metode analisis data yang alat penentunya berada di luar, terlepas, dan tidak menjadi bagian bahasa (langue) yang bersangkutan atau diteliti. Jadi, alat penentu pada penelitian ini dilihat dari bahasa Jerman itu sendiri. Untuk menentukan peran semantis, digunakan daya pilah referensial, yaitu alat penentunya berupa referen bahasa. Menurut Kridalaksana dalam (Yusri, 2013: 27), referen bahasa adalah kenyataan atau unsur luar bahasa yang ditunjuk satuan kebahasaan. Selanjutnya, digunakan alat penentu daya pilah translasional karena alat penentunya berupa bahasa lain. Bahasa lain yang dimaksudkan adalah bahasa di luar bahasa peneliti.

Penyajian hasil analisis data dalam penelitian ini dilakukan dengan menggunakan teknik informal. Metode penyajian informal adalah perumusan hasil penelitian dengan menggunakan kata-kata biasa (Sudaryanto, 2015: 241). Secara teknis, metode penyajian informal dinyatakan dalam bentuk pernyataan verbal yang singkat, tepat, dan jelas. 


\section{HASIL DAN PEMBAHASAN}

Pada sub bagian ini penulis akan memaparkan hasil penelitian mengenai representasi kecantikan dalam iklankecantikan Nivea. Iklan Nivea yang diteliti terdiri dari 3 iklan, yaitu Nivea Urban Skin, Nivea Vital Soja, dan Nivea Hyaluron Cellular Filler.

\subsection{Deskripsi dan Makna Tanda Verbal dan Nonverbal dalam Iklan Nivea}

Pada penelitian ini untuk mendeskripsikan tanda verbal dan nonverbal mengacu pada semiotika tanda Pierce yang membagi tanda menjadi ikon, indeks, dan simbol. Pemaknaan denotasi iklan mengacu pada penggunaan bahasa dengan arti yang sesuai dengan yang ditangkap oleh panca indera penglihatan. Pemaknaan konotasi sesuai dengan semiotika Roland Barthes, dalam hal ini makna konotasi telah terjadi sedikit pergeseran makna dari denotasi karena sudah ada penambahan rasa dan nilai tertentu.

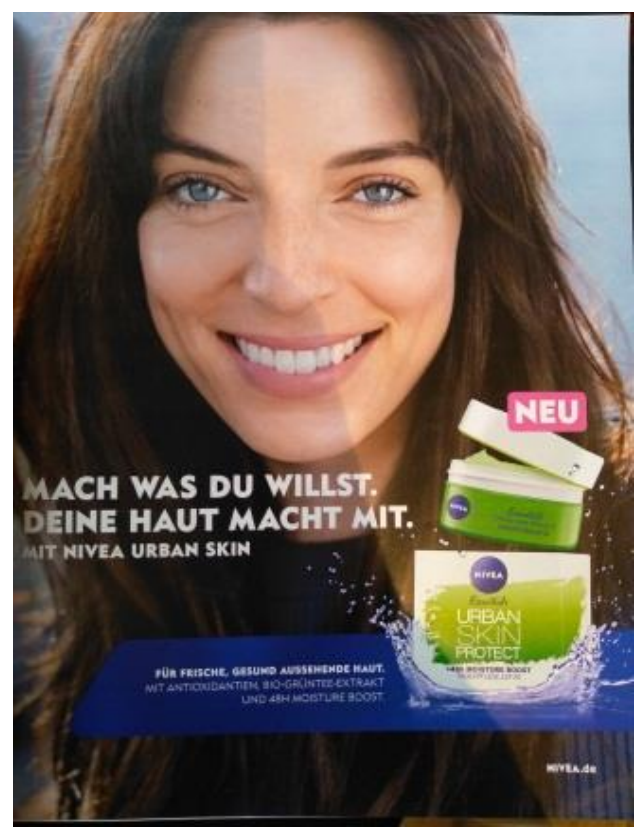

Gambar 1. Nivea Urban Skin

Gambar 1 yang merupakan iklan kecantikan Nivea terdapat seorang perempuan tersenyum dengan rambut terurai berwarna coklat tua. Riasan wajah perempuan tersebut tampak alami. Pada sisi kanan bawah terdapat gambar produk yang dipasarkan yaitu Nivea Urban Skin. Warna dari produk tersebut hijau dan mengindikasikan adanya kandungan teh hijau di dalam produk Nivea tersebut. Pada atas produk terdapat tulisan Neu dalam kamus Jerman-Indonesia ((Heuken, 2009; 345) berarti baru dengan warna latar belakang tulisan merah muda. Terdapat pula tulisan yang berlatarbelakang warna biru pada bagian bawah iklan. Pada sisi kiri bawah terdapat headline yang bertujuan untuk menarik perhatian pembaca. Dapat dilihat dalam kalimat: 
$\frac{\text { Mach }}{\text { lakukan apa }} \frac{\text { was }}{\text { kamu }} \quad \frac{\text { willst. }}{\text { ingin }} \frac{\text { deine }}{\text { kamu }} \quad \frac{\text { Haut }}{\text { kulit }} \quad \frac{\text { macht }}{\text { melakukan dengan }}$ Mit Nivea Urban Skin.

dengan Nivea Urban Skin

'Lakukan apapun yang kamu inginkan. Kulitmu mengikutimu. Dengan Nivea Urban Skin.'

Pada bagian bodycopy yang berlatar belakang warna biru terdapat tulisan: Für Frische, Gesund Aussehende Haut. untuk segar, sehat tampak kulit. 'untuk kulit tampak segar dan sehat.'

$\frac{\text { Mit }}{\text { dengan }} \frac{\text { Antioxidantien- }}{\text { antioksidan- }}-\frac{\text { Bio }}{\text { bio Grüntee- Extrakt }} \frac{\text { und }}{\text { teh hijau ekstra }} \frac{48 \mathrm{H}}{\text { dan }}$ Moisture Boost.

lembab meningkat.

'Dengan antioksidan ekstra bio teh hijau dan melembabkan selama 48 jam.'

Dari uraian di atas, berdasarkan teori tanda semiotika Peirce, gambar produk Nivea Urban Skin yang berwarna hijau merupakan tanda ikon, karena mewakili produk yang dijual yaitu Nivea Urban Skin. Nama produk adalah Nivea Urban Skin yang merupakan tanda indeks, karena mengindikasikan sumber acuan dan memiliki kedekatan dengan yang diwakilinya yaitu produk Nivea Urban tersebut. Kalimat-kalimat pada headline dan bodycopy merupakan tanda simbol, karena pada kalimat-kalimat tersebut mengindikasikan tujuan dari fungsi produk Nivea itu sebagai produk yang dapat melembabkan kulit wajah perempuan. Gambar model perempuan dan warna-warna yang digunakan dalam iklan juga merupakan tanda simbol, karena menggambarkan yang diharapkan produsen kepada konsumen setelah pemakaian produk.

Dari tanda verbal yang terdapat dalam gambar 1 muncul makna denotasi dan makna konotasi. Dilihat dari tanda verbalnya, secara denotasi pembuat iklan ingin menawarkan produk Nivea baru yaitu Nivea Urban Skin. Dengan adanya kalimat Mach Was Du Willst. Deine Haut Macht Mit. Mit Nivea Urban Skin. 'Lakukan apapun yang kamu inginkan. Kulitmu mengikuti dirimu. Dengan Nivea Urban Skin.' Pengguna produk dapat melakukan apapun dengan menggunakan produk Nivea Urban Skin dengan kandungan teh hijau yang dapat melembabkan kulit selama 48 jam. Kelembaban kulit akan selalu terjaga mengikuti cara yang dipilih oleh seseorang untuk merawat kulitnya. Dalam iklan ini yaitu dengan memilih produk Nivea Urban Skin. Adanya kata Urban pada nama produk, pengiklan berharap agar dapat memberikan yang terbaik untuk kulit terutama untuk kaum urban.

Secara konotasi, iklan Nivea Urban Skin ini mempunyai makna, cantik itu dapat melakukan apapun yang diinginkan dengan kulit yang sehat dan segar. Menurut pengiklan, perempuan cantik di Jerman itu dipandang ketika dapat 
secara leluasa beraktivitas dengan memiliki kulit yang sehat, segar, percaya diri, serta tampil dalam kesederhanaan. Hal ini tercermin dari tanda-tanda verbal dan non verbal muncul dalam iklan Nivea Urban Skin. Pada tanda verbal terdapat kalimat Für Frische, Gesund Aussehende Haut. 'untuk kulit tampak segar dan sehat.', yang bermakna bahwa cantik itu mempunyai kulit segar dan sehat. Begitupun dengan tanda nonverbal yang muncul yaitu dengan penggunaan warna hijau yang mengacu pada kandungan produk tersebut dari ekstra teh hijau pada produk memberikan arti percaya diri dan warna biru yang mendominasi pada iklan memberikan makna kesederhanaan. Penggunaan gambar perempuan yang terlihat cantik alami dan sederhana ini juga sebagai contoh bahwa dengan menggunakan produk Nivea tersebut kulit bisa menjadi sehat, segar dan terlihat cantik.

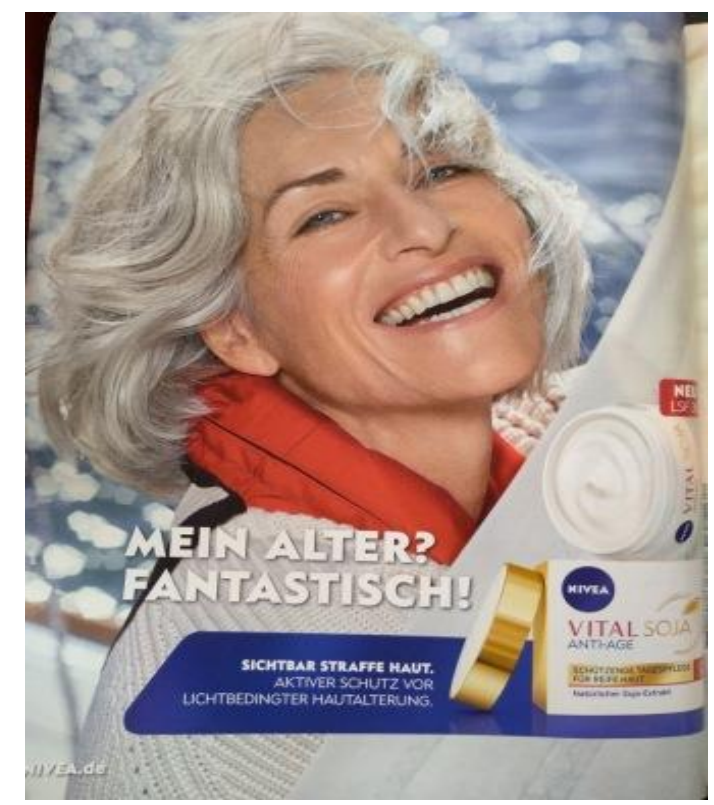

Gambar 2. Nivea Vital Soja

Pada gambar 2 merupakan iklan Nivea Vital Soja terdapat seorang perempuan dengan usia sekitar 45 tahun ke atas tertawa dengan rambut ikal pendek berwarna blonde. Riasan wajah perempuan tersebut tampak alami. Pada sisi kanan bawah terdapat gambar produk yaitu Nivea Vital Soja. Warna dari produk tersebut yaitu putih dan terdapat warna emas pada bagian tutup produk. Warna dominan dalam pada gambar 3 yaitu putih dan biru. Pada iklan tersebut terdapat pula headline yang menggunakan huruf kapital yaitu:

$\frac{\text { Mein }}{\text { saya }} \frac{\text { Alter? }}{\text { umur }} \frac{\text { Fantastisch! }}{\text { fantastis }}$

'Umur saya? Fantastis!' 
Pada bagian Fließtext/bodycopy yang terletak pada sisi bawah dengan warna latar belakang berwarna biru terdapat tulisan:

$\underline{\text { Sichtbar Straffe Haut. }}$.

terlihat ketat kulit

'Kulit tampak kencang'

$\frac{\text { Aktiver }}{\text { aktif }} \frac{\text { Schutz }}{\text { perlindungan terhadap sinar matahari }} \quad \frac{\text { vor }}{\text { penuaan kulit }}$

'Perlindungan aktif terhadap penuaan kulit dari paparan sinar matahari.'

Dari uraian di atas, berdasarkan teori tanda semiotika Peirce, gambar produk Nivea Vital Soja yang berwarna putih merupakan tanda ikon, karena mewakili produk yang dipasarkan. Nama produk dalam gambar 2 yaitu Nivea Vital Soja merupakan tanda indeks, karena mengindikasikan sumber acuan dan memiliki kedekatan dengan yang diwakilinya yaitu produk Nivea tersebut. Kalimat-kalimat pada headline dan bodycopy merupakan tanda simbol, karena pada kalimat-kalimat tersebut mengindikasikan tujuan dari fungsi produk Nivea itu sebagai produk yang dapat mengencangkan kulit wajah perempuan usia 45 tahun ke atas. Gambar model perempuan dan warna-warna yang digunakan dalam iklan juga merupakan tanda simbol, karena menggambarkan tujuan yang diharapkan produsen kepada konsumen setelah pemakaian produk yaitu kulit wajah menjadi lebih kencang.

Dari tanda verbal yang terdapat dalam gambar 2 muncul makna denotasi dan makna konotasi. Dilihat dari tanda verbalnya, secara denotasi pembuat iklan ingin menawarkan produk Nivea untuk kulit wajah yaitu Nivea Vital Soja. Dengan adanya kalimat Mein Alter? Fantastisch! 'Umur saya? Fantastis!' pada headline yang menunjukkan bahwa produk Nivea ini ditujukan untuk perempuan yang tidak perlu khawatir dengan penuaan pada kulit akibat dari sinar matahari langsung. Dari sinar matahari ini terdapat dalam kalimat Aktiver Schutz vor Lichtbedingter Hautalterung. 'Perlindungan aktif terhadap penuaan kulit dari paparan sinar matahari.' Pengguna juga diharapkan memiliki kulit wajah yang kencang walau sudah berusia lanjut terlihat dalam kalimat pada bodycopy yaitu Sichtbar Straffe Haut 'kulit tampak kencang', karena produk Nivea Vital Soja ini dapat berfungsi untuk mengencangkan kulit bagi perempuan. Produk tersebut sangat membantu perawatan kulit bagi usia lanjut terhadap paparan sinar matahari.

Secara konotasi, iklan Nivea Vital Soja tersebut memberikan makna para perempuan pengguna Nivea dapat tetap tampil cantik dan memiliki kulit kencang di usia lanjut. Pengguna produk diharapkan tetap terlihat cantik di usia 45 tahun ke atas. Dalam headline tertulis Mein Alter? Fantastisch! 'Umur saya? Fantastis!' yang memberikan makna bahwa perempuan cantik itu tidak perlu khawatir dengan masalah kulit dari sinar matahari dan seiring bertambahnya usia. Perempuan pengguna produk Nivea ini dapat tetap telihat muda dari usia sebenarnya dengan kulit wajah yang tetap kencang dengan sedikit masalah 
penuaan kulit. Penggunaan model perempuan yang berusia 45 tahun ke atas juga menyimbolkan bahwa produk tersebut dirancang khusus untuk perempuan yang sudah berusia lanjut agar tetap tampil cantik, mempunyai kulit kencang, tetap sederhana, dan cerdas dalam memilih produk perawatan kulit wajah. Sederhana ini tercermin dalam penggunaan warna dalam iklan yang didominasi warna putih yang menurut Seeman berarti kesederhanaan dan penggunaan warna biru yang berarti kecerdasan.

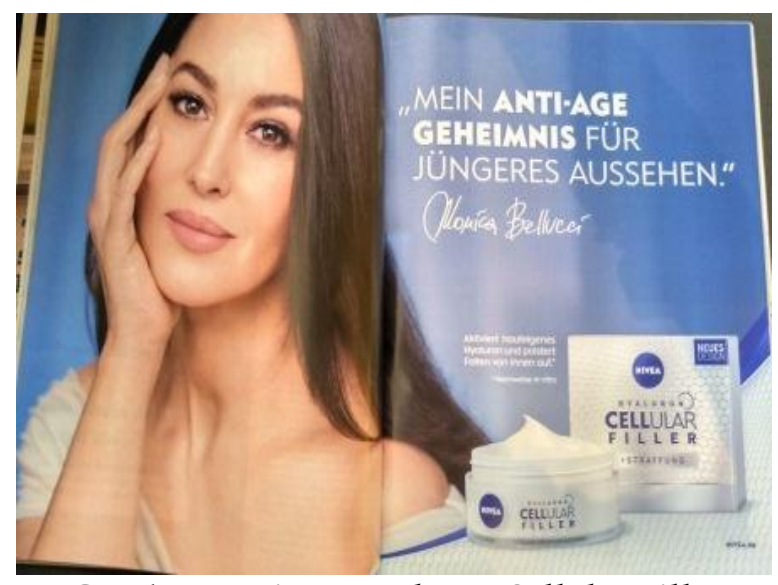

Gambar 3. Nivea Hyaluron Cellular Filler

Gambar 3 merupakan iklan Nivea Hyaluron Cellular Filler dengan terdapat seorang perempuan. Perempuan tersebut tersenyum dengan tangan menopang kepalanya. Perempuan tersebut memiliki rambut panjang terurai berwarna hitam. Perempuan tersebut merupakan seorang artis terkenal asal Italia bernama Monica Belluci dan dalam iklan namanya tertulis jelas di bawah headline. Pada sisi kanan bawah terdapat gambar produk yang dipasarkan yaitu produk Nivea Hyaluron Cellular Filler dan produk tersebut berwarna putih.Warna dalam iklan tersebut didominasi dengan warna latar belakang biru. Pada sisi kanan atas terdapat headline yang ditulis dengan kalimat sebagai berikut:

$\frac{\text { Mein }}{\text { saya Anti-Age geheimnis für }} \frac{\text { jüngeres }}{\text { anti-usia }} \frac{\text { aussehen. }}{\text { rahasia }}$

'Rahasia anti kerut saya untuk terlihat muda'

Pada bagian Fließtext/bodycopy terdapat tulisan:

Aktiviert hauteigenes Hyaluron und polstert Falten von innen auf. ${ }^{*}$

Aktif kulit hialuron dan melapisi kerutan dari dalam di

'Kandungan aktif hialuron yang dapat melapisi kerutan dari dalam.'

*Nachweise in vitro

petunjuk di kertas

petunjuk di kertas'

Berdasarkan teori tanda semiotika Peirce, gambar produk Nivea Hyaluron Cellular Filler yang berwarna putih merupakan tanda ikon, karena mewakili 
produk yang dipasarkan. Nama produk dalam gambar 2 yaitu Nivea Hyaluron Cellular Filler merupakan tanda indeks, karena mengindikasikan sumber acuan dan memiliki kedekatan dengan yang diwakilinya yaitu produk Nivea tersebut. Kalimat-kalimat pada headline dan bodycopy merupakan tanda simbol, karena pada kalimat-kalimat tersebut mengindikasikan tujuan dari fungsi produk Nivea itu sebagai produk yang dapat menghilangkan kerutan pada kulit wajah. Gambar model perempuan dan warna-warna yang digunakan dalam iklan juga merupakan tanda simbol, karena menggambarkan tujuan yang diharapkan produsen kepada konsumen agar kulit wajah tetap terlihat muda karena produk Nivea tersebut dapat mengurangi kerutan kulit wajah.

Dari tanda verbal yang terdapat dalam gambar 2 muncul makna denotasi dan makna konotasi. Dilihat dari tanda verbalnya, secara denotasi pembuat iklan ingin menawarkan produk Nivea untuk perawatan kulit wajah yaitu Nivea Hyaluron Cellular Filler. Pada headline tertulis Mein Anti-Age geheimnis für jüngeres aussehen. 'Rahasia anti kerut saya untuk terlihat muda.' yang menunjukkan bahwa produk Nivea tersebut merupakan salah satu resep untuk menghilangkan kerutan pada kulit wajah sehingga perempuan yang tidak perlu khawatir dengan masalah penuaan pada kulit wajah. Produk tersebut mengandung Hyaluron yang dapat melapisi kerutan pada kulit wajah dan diharapkan tampak terlihat muda.

Secara konotasi, iklan Nivea Hyaluron Cellular Filler tersebut memberikan makna perempuan pengguna Nivea tersebut dapat tetap terlihat muda dan cantik di usia lanjut. Pengguna produk diharapkan tetap terlihat cantik tanpa ada kerutan di wajah Perempuan pengguna produk Nivea Hyaluron Cellular Filler ini dapat tetap telihat muda dari usia sebenarnya dengan kulit wajah yang tidak ada kerutan. Penggunaan model perempuan Monica Belluci menjadi standar kecantikan bagi pengguna produk tersebut juga menyimbolkan bahwa produk tersebut dirancang khusus untuk perempuan yang sudah berusia 45 tahun ke atas tetap tampil cantik, tidak ada kerutan, tetap sederhana, dan cerdas dalam memilih produk perawatan kulit wajah. Selain itu, dengan dipilihnya model asal Italia tersebut juga menandakan bahwa produk Nivea ini telah dipercaya di negara lain sebagai produk perawatan wajah. Sederhana ini tercermin dalam penggunaan warna dalam iklan yang didominasi warna putih yang menurut Seeman berarti kesederhanaan dan penggunaan warna biru yang berarti kecerdasan.

\subsection{Reperesentasi Kecantikan dalam Iklan Nivea Berbahasa Jerman}

Kecantikan perempuan di Jerman bahkan di seluruh dunia sangatlah beragam. Masing-masing mempunyai standar kecantikan yang berbeda-beda. Seiring berkembangnya zaman dan munculnya tren dari perawatan kecantikan yang lebih modern membuat para perempuan berlomba-lomba memilih cara perawatan yang terbaik untuk kulitnya. Begitu pula dengan kandungan atau bahan dasar yang terdapat pada kosmetik yang selalu baru dengan penemuan terbaru dari para peneliti di bidangnya. 
Secara keseluruhan, iklan Nivea berbahasa Jerman dari gambar 1 hingga gambar 3 menampilkan model perempuan serta gambar produk sebagai ikon. Produk Nivea sebagai produk yang telah mendunia saat ini tidak hanya menampilkan model perempuan asli Jerman saja tetapi juga menampilkan model dari luar negara Jerman. Ciri khas cantik dari perempuan Jerman secara keseluruhan dari iklan Nivea yaitu yang mempunyai kulit sehat, segar, kencang, dan tetap menjaga kulit tampak muda. Hal ini dapat dilihat dari penggunaan tanda verbal yang menggunakan kata-kata frischer, straffer, gesund, atau jungeres. Perempuan cantik juga dapat tampil percaya diri dan cerdas, walaupun tampil dalam kesederhanaan. Hal ini tergambar seperti pada penggunaan tanda nonverbal dalam iklan yaitu pada penggunaan warna tampilan iklan dan gambar perempuan yang tampak sederhana dengan riasan wajah yang natural tidak berlebihan. Warna dominan yang digunakan dalam iklan Nivea yaitu putih dan biru.

Dilihat dari produk kecantikan Nivea yang diiklankan hampir semuanya bertujuan untuk membuat kulit tampak sehat, kencang, dan tampak lebih muda. Ini berarti yang diinginkan para perempuan di Jerman untuk tampil cantik yaitu dengan memiliki kulit yang sehat dan kencang, serta tampak lebih muda dari usianya. Tentunya dengan selalu menjaga kulit tetap sehat, perempuan akan lebih leluasa beraktivitas tanpa harus takut masalah pada kulit. Mengingat, Jerman sebagai negara 4 musim, setiap perubahan musim ini akan berpengaruh terhadap kesehatan kulit. Jika tidak menjaga pola hidup sehat, masyarakat akan rentan terhadap masalah pada kulit, terutama bagi yang memiliki kulit sensitif.

\section{PENUTUP}

Berdasarkan hasil penelitian yang telah dilakukan, maka dapat disimpulkan bahwa pembuat iklan secara keseluruhan menampilkan model perempuan sebagai ikon dalam iklan, hal ini bertujuan untuk menarik perhatian para perempuan sebagai konsumen utama. Dalam iklan kecantikan Nivea berbahasa Jerman juga terdapat berbagai makna yang terkandung. Dari makna denotasi dan konotasi yang muncul dalam iklan dapat merepresentasikan kecantikan perempuan Jerman dengan mempunyai ciri khas cantik yaitu mempunyai kulit segar, kencang, dan tetap menjaga kulit tampak lebih muda. Perempuan cantik Jerman juga mampu tampil sederhana dan memiliki kecerdasan yang baik.

\section{DAFTAR PUSTAKA}

Barthes, R. (2012). Elemen-elemen Semiologi (Terjemahan Nazarudin). Yogyakarta: Jalasutra.

Danesi, M. (2010). Pengantar Memahami Semiotika Media. Yogyakarta: Jalasutra.

Danesi, M. (2012). Pesan, Tanda, dan Makna: Buku Teks Dasar Mengenai Semiotika dan Teori Komunikasi. Yogyakarta: Jalasutra.

Departemen Pendidikan Nasional, P. B. (2008). Kamus Besar Bahasa Indonesia. Jakarta: Balai Pustaka. 
Dewi, M. C. (2013). Analisis Semiotika Charles Sanders Peirce pada Iklan Kosmetik Wardah di Tabloid Nova. Jurnal Komunikasi PROFETIK, 06(2), 6382.

Djajasudarma, F. (2010). Metode Linguistik: Ancangan Metode Penelitian dan Kajian. Bandung: PT Refika Aditama.

Heuken, A. (2009). Kamus Jerman-Indonesia, Deutsches-Indonesisch Wörterbuch. Jakarta: PT Gramedia Pustaka Utama.

Janich, N. (2010). Werbesprache: Ein Arbeitsbuch, 5. Erweiterte Auflage. Tübingen: Naar Francke Attempto Verlag.

Nöth, W. (2000). Handbuch der Semiotik. Stuttgart: Weimar: J.B Metzler Verlag.

Razum, K. K.-. (2010). Duden 10 Das Bedeutungs- wörterbuch. Mannheim: Bibliographisches Institut $\mathrm{GmbH}$.

Schlüter, S. (2007). Die Sprache der Werbung: Entwicklungen, Trends und Beispiele. Saarbrücken: VDM Verlag Dr. Müller.

Sebayang, C. M. (2017). Analisis Semiotika Representasi Kecantikan pada Iklan Pantene Total Damage Care 10 Versi Raline Shah di Media Televisi. EJournal Ilmu Komunikasi, 5(2), 66-80.

Situmeang, I. O. (2015). Representasi Wanita pada Iklan Televisi Wardah Cosmetic. Semiotika, 9(1), 113-141.

Sudaryanto. (2015). Metode dan Aneka Teknik Analisis Bahasa: Pengantar Penelitian Wahana Kebudayaan secara Linguistis. Yogyakarta: Duta Wacana University Press.

Winarni, R. W. (2010). Representasi Kecantikan Perempuan dalam Iklan. Deiksis, 2(2), 134-152.

Yusri, L. D. (2013). Analisis Bahasa dan Simbol pada Iklan Kemasan Sabun Mandi Shinzui. Journal Polingua Scientific Journal of Linguistics, Literature and Education, 2(1), 25-31.

Zulkarnaen, A. G., \& Ajie, R. M. A. . (2014). Citra Pria Indonesia dan Jerman pada Iklan Produk Nivea Men Ditinjau dari Aspek Semantis dan Semiotis. FIB UI, 1-22. 